\section{Kidney \\ Blood Pressure Research}

Kidney Blood Press Res 2012;36:47-54

DOI: 10.1159/000339027

Published online: July 24, 2012

Accepted: June 26, 2012

\title{
Hypobilirubinemia Might be a Possible Risk Factor of End-Stage Kidney Disease Independently of Estimated Glomerular Filtration Rate
}

\author{
Eiji Oda $^{1}$ Ryuzi Aoyagi ${ }^{2}$ Yoshifusa Aizawa ${ }^{3}$ \\ ${ }^{1}$ Tachikawa Medical Check-up Center, Tachikawa Medical Center, Nagaoka, Japan, ${ }^{2}$ Chuetsu Kidney \\ Center, Tachikawa Medical Center, Nagaoka, Japan, ${ }^{3}$ Department of Research and Development, \\ Tachikawa Medical Center, Nagaoka, Japan
}

\section{Key Words}

Bilirubin • Chronic kidney disease • Estimated GFR • End-Stage kidney disease

\begin{abstract}
Background/Aims: The relationship between serum total bilirubin (TB) and estimated glomerular filtration rate (eGFR) is controversial and there is no report on the association between TB and end-stage kidney disease (ESKD). Methods: We examined the cross-sectional association between TB and eGFR and investigated whether TB can predict ESKD with multivariable logistic regression adjusted for age, sex, and baseline eGFR using hospital-based data. Results: The geometric mean TB of patients with eGFR $\geq 90 \mathrm{~mL} / \mathrm{min} / 1.73 \mathrm{~m}^{2}$ (S1), 89$60 \mathrm{~mL} / \mathrm{min} / 1.73 \mathrm{~m}^{2}$ (S2), $59-30 \mathrm{~mL} / \mathrm{min} / 1.73 \mathrm{~m}^{2}$ (S3), $29-15 \mathrm{~mL} / \mathrm{min} / 1.73 \mathrm{~m}^{2}$ (S4), and < 15 $\mathrm{mL} / \mathrm{min} / 1.73 \mathrm{~m}^{2}$ (S5 = ESKD) was $0.55 \mathrm{mg} / \mathrm{dL}, 0.59 \mathrm{mg} / \mathrm{dL}, 0.56 \mathrm{mg} / \mathrm{dL}, 0.47 \mathrm{mg} / \mathrm{dL}$, and 0.36 $\mathrm{mg} / \mathrm{dL}$ (all $p<0.0001$ except for S1 vs. S3 where $p=0.3726$ ), respectively excluding patients with hyperbilirubinemia ( $\mathrm{TB}>1.24 \mathrm{mg} / \mathrm{dL}$ ). The odds ratio ( $95 \%$ confidence interval) of incident ESKD for each $0.1 \mathrm{mg} / \mathrm{dL}$ increase in TB and hypobilirubinemia defined as TB $\leq 0.34 \mathrm{mg} / \mathrm{dL}$ were $0.92(0.80-1.07)(p=0.2804)$ and $3.51(1.56-7.88)(p=0.0023)$, respectively in patients with baseline eGFR $\geq 15 \mathrm{~mL} / \mathrm{min} / 1.73 \mathrm{~m}^{2}$ and $0.59(0.37-0.95)(p=0.0283)$ and $6.03(1.63-22.30)$ $(p=0.0071)$, respectively in patients with baseline eGFR $29-15 \mathrm{~mL} / \mathrm{min} / 1.73 \mathrm{~m}^{2}$. Conclusions: Hypobilirubinemia might be a possible risk factor of ESKD.
\end{abstract}




\section{Kidney Blood Pressure Research}

Kidney Blood Press Res 2012;36:47-54

\begin{tabular}{l|l} 
DOI: $10.1159 / 000339027$ & (c) 2012 S. Karger AG, Basel
\end{tabular}

Published online: July 24, 2012

www.karger.com/kbr

\section{Introduction}

The prevalence of chronic kidney disease (CKD) is increasing worldwide [1]. Reduced estimated glomerular filtration rate (eGFR) and increased urinary albumin excretion are established risk factors of end-stage renal disease (ESKD) [2, 3], cardiovascular disease (CVD), and all-cause mortality [3-7]. The identification of additional risk factors of ESKD other than known risk factors such as reduced eGFR and increased urinary excretion of albumin may be helpful for patients with CKD to predict future ESKD and to prevent from the disease progression to ESKD. Bilirubin is a potent antioxidant [8] and some epidemiological studies suggest that low levels of serum total bilirubin (TB) may be a risk factor of CVD [9-11]. Information on the association between TB and eGFR is limited and controversial. Fukui et al. found that TB was positively associated with eGFR and negatively associated with albuminuria in Japanese diabetic patients [12]. Shin et al. reported similar results in Korean diabetic and non-diabetic adults [13], indicating that bilirubin has a potential renoprotective effect. In contrast, Targher et al. found that a higher TB was significantly associated with lower eGFR both in hospital-based unselected outpatients [14] and in the US general population [15], suggesting fatty liver disease as a link between increased TB and decreased eGFR. However, these reports are all cross-sectional studies while whether TB can predict future ESKD has not been studied yet. Therefore, we examined the cross-sectional association between TB and eGFR using data from 14508 unselected patients whose TB and eGFR were simultaneously measured and investigated whether TB can predict incident ESKD defined as eGFR $<15 \mathrm{~mL} / \mathrm{min} / 1.73 \mathrm{~m}^{2}$ using data of unselected 6251 patients with baseline eGFR $\geq 15$ $\mathrm{mL} / \mathrm{min} / 1.73 \mathrm{~m}^{2}$ whose TB and eGFR were simultaneously measured in the next year. This study was approved by the ethics committee in Tachikawa Medical Center.

\section{Subjects and Methods}

Simultaneously measured TB and creatinine data at the biochemical laboratory of our Medical Center in 2009 and 2010 were all collected. The data of the first time measurements were used for each patient who underwent multiple measurements in the same year. The numbers (male/female) of the patients were 14508 (8 177/6 331) in 2009 and 14552 (8 199/6 353) in 2010. The data in 2009 were used in the cross-sectional study. The data in 2009 and 2010 of the same patients were paired excluding patients with baseline eGFR $<15 \mathrm{~mL} / \mathrm{min} / 1.73 \mathrm{~m}^{2}$ in 2009 , resulting in 6251 pairs which were used for the longitudinal study. Hospital records of 28 patients who developed new ESRD were reviewed.

\section{Biochemical measurements and calculations of eGFR}

TB and serum creatinine were measured by enzymatic methods on an automatic analyzer TBAc16000 (Toshiba, Tokyo, Japan). In this assay system, the physiological range of TB was $0.3-1.2 \mathrm{mg} / \mathrm{dL}$ and that of creatinine was $0.65-1.09 \mathrm{mg} / \mathrm{dL}$ in men and $0.46-0.82 \mathrm{mg} / \mathrm{dL}$ in women. eGFR was calculated from serum creatinine with the gender-specific equations for Japanese recommended by the Japanese Society of Nephrology [16].

\section{Statistical analysis}

Stages of renal dysfunction were defined according to the CKD staging [17]; namely, eGFR $\geq 90 \mathrm{~mL} /$ $\mathrm{min} / 1.73 \mathrm{~m}^{2}$ (S1), 89-60 mL/min/1.73 m² (S2), 59-30 mL/min/1.73 m² (S3), 29-15 mL/min/1.73 m2 (S4), and $<15 \mathrm{~mL} / \mathrm{min} / 1.73 \mathrm{~m}^{2}$ (S5 = ESKD). TB $<0.25 \mathrm{mg} / \mathrm{dL}$ was found in $1.8 \%$ and $\mathrm{TB}<0.35 \mathrm{mg} / \mathrm{dL}$ was found in $9.7 \%$ of patients. In this study, we conveniently called $\mathrm{TB} \leq 0.34 \mathrm{mg} / \mathrm{dL}$ as hypobilirubinemia. $\mathrm{TB}>1.24$ $\mathrm{mg} / \mathrm{dL}$ was considered hyperbilirubinemia indicating possible liver diseases because $\mathrm{TB}>1.24 \mathrm{mg} / \mathrm{dL}$ was found in $4.5 \%$ of patients. Geometric mean TB was calculated for each stage of renal dysfunction using 2009 data including and excluding patients with hyperbilirubinemia because TB was not distributed normally. Odds ratios (ORs) of eGFR $<15 \mathrm{~mL} / \mathrm{min} / 1.73 \mathrm{~m}^{2},<30 \mathrm{~mL} / \mathrm{min} / 1.73 \mathrm{~m}^{2}$, and $<60 \mathrm{~mL} / \mathrm{min} / 1.73 \mathrm{~m}^{2}$ were calculated for each $0.1 \mathrm{mg} / \mathrm{dL}$ increase in TB and hypobilirubinemia adjusting for age and sex including and excluding patients with hyperbilirubunemia using 2009 data. ORs of incident ESKD in 2010 were calculated for each $0.1 \mathrm{mg} / \mathrm{dL}$ increase in TB (mg/dL) and hypobilirubinemia adjusting for age, sex, and baseline eGFR 


\section{Kidney Blood Pressure Research}

Kidney Blood Press Res 2012;36:47-54

\begin{tabular}{l|l} 
DOI: $10.1159 / 000339027$ & C 2012 S. Karger AG, Basel
\end{tabular}

Published online: July 24, 2012 www.karger.com/kbr

Oda/Aoyagi/Aizawa: Bilirubin and End-Stage Kidney Disease

Table 1. Geometric mean total bilirubin (TB) in each category of estimated glomerular filtration rate (eGFR) including and excluding patients with hyperbilirubinemia (TB $>1.24 \mathrm{mg} / \mathrm{dL}$ )

\begin{tabular}{|c|c|c|c|c|c|}
\hline & S1 & $\mathrm{S} 2$ & S3 & S4 & S5 \\
\hline $\begin{array}{c}\text { eGFR } \\
\left(\mathrm{mL} / \mathrm{min} / 1.73 \mathrm{~m}^{2}\right)\end{array}$ & $90 \leq$ & $60-89$ & $30-59$ & $15-29$ & $<15$ \\
\hline \multicolumn{6}{|c|}{ including patients with hyperbilirubinemia $(n=14508)$} \\
\hline $\mathrm{n}$ & 1983 & 7889 & 4031 & 390 & 215 \\
\hline female $(\%)$ & 48.9 & 41.6 & 44.7 & 51.3 & 38.6 \\
\hline age (years) & $49.1 \pm 19.6$ & $63.8 \pm 14.7$ & $74.4 \pm 10.9$ & $77.7 \pm 12.3$ & $70.1 \pm 13.8$ \\
\hline $\mathrm{TB}(\mathrm{mg} / \mathrm{dL})$ & $0.59 \pm 1.65 \mathrm{a}$ & $0.63 \pm 1.56$ a & $0.60 \pm 1.61 \mathrm{a}$ & $0.54 \pm 1.82 \mathrm{a}$ & $0.37 \pm 1.76 \mathrm{a}$ \\
\hline \multicolumn{6}{|c|}{ excluding patients with hyperbilirubinemia $(\mathrm{n}=13647)$} \\
\hline $\mathrm{n}$ & 1868 & 7426 & 3789 & 354 & 210 \\
\hline female $(\%)$ & 50.2 & 42.4 & 45.4 & 53.1 & 38.1 \\
\hline age (years) & $49.0 \pm 19.7$ & $63.9 \pm 14.7$ & $74.5 \pm 10.8$ & $77.7 \pm 12.3$ & $70.2 \pm 13.9$ \\
\hline $\mathrm{TB}(\mathrm{mg} / \mathrm{dL})$ & $0.55 \pm 1.49 \mathrm{~b}$ & $0.59 \pm 1.44^{b}$ & $0.56 \pm 1.47^{b}$ & $0.47 \pm 1.54^{b}$ & $0.36 \pm 1.69^{b}$ \\
\hline $\mathrm{p}=0.7393$ (S1 vs & )$=0.0132 \mathrm{CS}$ & S. S4), $=0.000$ & (S3 vs. S4), $<$ & $\begin{array}{l}0001 \text { (all othe } \\
\text { where } \mathrm{p}=0.3\end{array}$ & \\
\hline
\end{tabular}

including and excluding patients with hyperbilirubunemia and by baseline renal function. Means were compared with Scheffe's tests after ANOVA. Statistical analysis was performed using Dr SPSS-2 (IBM Japan, Tokyo, Japan). P values of lower than 0.05 were considered significant.

\section{Results}

Cross-sectional associations between TB and eGFR

The geometric mean TB of patients whose TB and eGFR were simultaneously measured in 2009 are presented by eGFR categories in Table 1 . The geometric mean TB was $0.59 \mathrm{mg} /$ $\mathrm{dL}, 0.63 \mathrm{mg} / \mathrm{dL}, 0.60 \mathrm{mg} / \mathrm{dL}, 0.54 \mathrm{mg} / \mathrm{dL}$, and $0.47 \mathrm{mg} / \mathrm{dL}$, respectively in $\mathrm{S} 1, \mathrm{~S} 2$, S3, S4, and S5 including patients with hyperbilirubinemia. The p values were $=0.7393$ for S1 vs. S3, $=0.0132$ for S1 vs. S4, 0.0006 for S3 vs. S4, and $<0.0001$ for all other comparisons. The geometric mean TB was $0.55 \mathrm{mg} / \mathrm{dL}, 0.59 \mathrm{mg} / \mathrm{dL}, 0.56 \mathrm{mg} / \mathrm{dL}, 0.47 \mathrm{mg} / \mathrm{dL}$, and $0.36 \mathrm{mg} / \mathrm{dL}$, respectively in S1, S2, S3, S4, and S5 excluding patients with hyperbilirubinemia. The p values were $<0.0001$ for all comparisons other than (S1 vs. S3) where the p value was 0.3726 . Table 2 shows the age- and sex-adjusted OR of renal dysfunction for each $0.1 \mathrm{mg} / \mathrm{dL}$ increase in TB and hypobilirubinemia including and excluding patients with hyperbilirubinemia. The OR was adjusted for age and sex because renal function is affected by age and sex. The OR ( $95 \%$ confidence interval (CI)) of eGFR $<15 \mathrm{~mL} / \mathrm{min} / 1.73 \mathrm{~m}^{2}$, eGFR $<30 \mathrm{~mL} / \mathrm{min} / 1.73 \mathrm{~m}^{2}$, and eGFR $<60 \mathrm{~mL} / \mathrm{min} / 1.73 \mathrm{~m}^{2}$ for each $0.1 \mathrm{mg} / \mathrm{dL}$ increase in TB and hypobilirubinemia was $0.59(0.54-0.64)(\mathrm{p}<0.0001)$ and $8.81(6.68-11.60)(\mathrm{p}<0.0001), 0.91(0.88-0.94)(\mathrm{p}<$ $0.0001)$ and $4.48(3.72-5.41)(\mathrm{p}<0.0001)$, and $0.993(0.986-0.999)(\mathrm{p}=0.0316)$ and 1.77 $(1.56-2.00)(\mathrm{p}<0.0001)$, respectively including patients with hyperbilirubinemia and 0.52 (0.47-0.57) $(\mathrm{p}<0.0001)$ and 8.60 (6.51-11.36) (p < 0.0001), $0.70(0.67-0.74)(\mathrm{p}<0.0001)$ and $4.65(3.84-5.62)(\mathrm{p}<0.0001)$, and $0.94(0.92-0.95)(\mathrm{p}<0.0001)$ and $1.78(1.57-2.02)(\mathrm{p}$ $<0.0001$ ), respectively excluding patients with hyperbilirubinemia.

\section{Longitudinal associations between baseline TB and incident ESKD in the next year}

Among 6251 patients whose TB and eGFR were simultaneously measured both in 2009 and in 2010 and whose baseline eGFR were $\geq 15 \mathrm{~mL} / \mathrm{min} / 1.73 \mathrm{~m}^{2}, 28$ patients newly developed ESKD in 2010, of which 24 cases were from 2165 patients with baseline eGFR of $15-59 \mathrm{~mL} / \mathrm{min} / 1.73 \mathrm{~m}^{2}$ and 18 cases were from 164 patients with baseline eGFR of 15-29 $\mathrm{mL} / \mathrm{min} / 1.73 \mathrm{~m}^{2}$. Baseline clinical backgrounds of patients who developed new ESKD are presented in Table 3. The mean follow-up period, age, eGFR, and TB were $10.3 \pm 5.0$ months, $76.2 \pm 11.9$ years, $33.3 \pm 23.7 \mathrm{~mL} / \mathrm{min} / 1.73 \mathrm{~m}^{2}$, and $0.53 \pm 0.36 \mathrm{mg} / \mathrm{dL}$, respectively and the baseline complication of diabetes, hypertension, and CVD were $42.9 \%, 75.0 \%$, and $64.3 \%$, respectively. Age-, sex-, and baseline eGFR-adjusted OR of ESKD for each $0.1 \mathrm{mg} / \mathrm{dL}$ increase 


\section{Kidney Blood Pressure Research}

Kidney Blood Press Res 2012;36:47-54

\begin{tabular}{l|l} 
DOI: $10.1159 / 000339027$ & C 2012 S. Karger AG, Basel
\end{tabular}

Published online: July 24, 2012

Table 2. Odds ratios of renal dysfunction for each $0.1 \mathrm{mg} / \mathrm{dL}$ increase in total bilirubin (TB) and hypobilirubinemia (TB $\leq 0.34 \mathrm{mg} / \mathrm{dL}$ ) adjusted for age and sex including and excluding patients with hyperbilirubinemia (TB $>1.24 \mathrm{mg} / \mathrm{dL}) .(95 \%)=$ 95\% confidence interval)

Oda/Aoyagi/Aizawa: Bilirubin and End-Stage Kidney Disease

\begin{tabular}{|c|c|c|}
\hline & odds ratio $(95 \%)$ & $\mathrm{p}$ \\
\hline \multicolumn{3}{|c|}{ including patients with hyperbilirubinemia $(\mathrm{n}=14508)$} \\
\hline \multicolumn{3}{|c|}{ for $\mathrm{eGFR}^{\mathrm{a}}<15 \mathrm{~mL} / \mathrm{min} / 1.73 \mathrm{~m}^{2}(\mathrm{n}=215)$} \\
\hline TB $(0.1 \mathrm{mg} / \mathrm{dL}$ increase $)$ & $0.59(0.54-0.64)$ & $<0.0001$ \\
\hline hypobilirubinemia & $8.81(6.68-11.60)$ & $<0.0001$ \\
\hline \multicolumn{3}{|c|}{ for eGFR ${ }^{\mathrm{a}}<30 \mathrm{~mL} / \mathrm{min} / 1.73 \mathrm{~m}^{2}(\mathrm{n}=605)$} \\
\hline TB $(0.1 \mathrm{mg} / \mathrm{dL}$ increase $)$ & $0.91(0.88-0.94)$ & $<0.0001$ \\
\hline hypobilirubinemia & $4.48(3.72-5.41)$ & $<0.0001$ \\
\hline \multicolumn{3}{|c|}{ for eGFR $a 60 \mathrm{~mL} / \mathrm{min} / 1.73 \mathrm{~m}^{2}(\mathrm{n}=4636)$} \\
\hline ТВ $(0.1 \mathrm{mg} / \mathrm{dL}$ increase $)$ & $0.993(0.986-0.999)$ & 0.0316 \\
\hline hypobilirubinemia & $1.77(1.56-2.00)$ & $<0.0001$ \\
\hline \multicolumn{3}{|c|}{ excluding patients with hyperbilirubinemia $(n=13647)$} \\
\hline \multicolumn{3}{|c|}{ for eGFR ${ }^{\mathrm{a}}<15 \mathrm{~mL} / \mathrm{min} / 1.73 \mathrm{~m}^{2}(\mathrm{n}=210)$} \\
\hline TB $(0.1 \mathrm{mg} / \mathrm{dL}$ increase $)$ & $0.52(0.47-0.57)$ & $<0.0001$ \\
\hline hypobilirubinemia & $8.60(6.51-11.36)$ & $<0.0001$ \\
\hline \multicolumn{3}{|c|}{ for $\mathrm{eGFR}^{\mathrm{a}}<30 \mathrm{~mL} / \mathrm{min} / 1.73 \mathrm{~m}^{2}(\mathrm{n}=564)$} \\
\hline TB $(0.1 \mathrm{mg} / \mathrm{dL}$ increase $)$ & $0.70(0.67-0.74)$ & $<0.0001$ \\
\hline hypobilirubinemia & $4.65(3.84-5.62)$ & $<0.0001$ \\
\hline \multicolumn{3}{|c|}{ for eGFR ${ }^{a}<60 \mathrm{~mL} / \mathrm{min} / 1.73 \mathrm{~m}^{2}(\mathrm{n}=4353)$} \\
\hline TB $(0.1 \mathrm{mg} / \mathrm{dL}$ increase $)$ & $0.94(0.92-0.95)$ & $<0.0001$ \\
\hline hypobilirubinemia & $1.78(1.57-2.02)$ & $<0.0001$ \\
\hline
\end{tabular}

Table 3.

\begin{tabular}{lc}
\hline \multicolumn{2}{l}{$\begin{array}{l}\text { Baseline clinical backgrounds of patients who } \\
\text { developed new end-stage kidney disease }\end{array}$} \\
\hline $\mathrm{n}$ (male/female) & $28(15 / 13)$ \\
follow-up months & $10.3 \pm 5.0$ \\
baseline age (years) & $76.2 \pm 11.9$ \\
baseline eGFR $\left(\mathrm{mL} / \mathrm{min} / 1.73 \mathrm{~m}^{2}\right)$ & $33.2 \pm 23.7$ \\
baseline total bilirubin (mg/dL) & $0.53 \pm 0.36$ \\
baseline complications & \\
diabetes (\%) & 42.9 \\
hypertension (\%) & 75.0 \\
cardiovascular disease (\%) & 64.3 \\
\hline a estimated glomerular filtration rate & \\
\hline
\end{tabular}

in TB and hypobilirubinemia are presented in Table 4. The adjusted OR (95\% CI) of ESKD for each $0.1 \mathrm{mg} / \mathrm{dL}$ increase in TB and hypobilirubinemia were $0.92(0.80-1.07)(p=0.2804)$ and $3.51(1.56-7.88)(\mathrm{p}=0.0023)$, respectively including patients with hyperbilirubinemia and $0.87(0.71-1.07)(\mathrm{p}=0.1901)$ and $3.46(1.53-7.85)(\mathrm{p}=0.0029)$, respectively excluding patients with hyperbilirubinemia among patients with baseline eGFR $\geq 15 \mathrm{~mL} / \mathrm{min} / 1.73 \mathrm{~m}^{2}$. The adjusted OR (95\% CI) of ESKD for each $0.1 \mathrm{mg} / \mathrm{dL}$ increase in TB and hypobilirubinemia were $0.92(0.78-1.09)(p=0.3560)$ and $3.21(1.31-7.80)(p=0.0102)$, respectively including patients with hyperbilirubinemia and $0.84(0.65-1.08)(\mathrm{p}=0.1700)$ and $3.24(1.30-8.09)$ $(\mathrm{p}=0.0115)$, respectively excluding patients with hyperbilirubinemia among patients with baseline eGFR of $15-59 \mathrm{~mL} / \mathrm{min} / 1.73 \mathrm{~m}^{2}$. The adjusted OR (95\% CI) of ESKD for each 0.1 $\mathrm{mg} / \mathrm{dL}$ increase in TB and hypobilirubinemia were $0.59(0.37-0.95)(\mathrm{p}=0.0283)$ and 6.03 $(1.63-22.30)(p=0.0071)$, respectively including patients with hyperbilirubinemia and 0.59 $(0.37-0.95)(p=0.0287)$ and $5.78(1.56-21.41)(p=0.0086)$, respectively excluding patients with hyperbilirubinemia among patients with baseline eGFR of $15-29 \mathrm{~mL} / \mathrm{min} / 1.73 \mathrm{~m}^{2}$. 


\section{Kidney Blood Pressure Research}

Kidney Blood Press Res 2012;36:47-54

\begin{tabular}{l|l}
\hline DOI: $10.1159 / 000339027$ & (c) 2012 S. Karger AG, Basel
\end{tabular}

Published online: July 24, 2012

www.karger.com/kbr

Table 4. Odds ratios of endstage kidney disease for each $0.1 \mathrm{mg} / \mathrm{dL}$ increase in total bilirubin (TB) and hypobilirubinemia (TB $\leq 0.34 \mathrm{mg} / \mathrm{dL}$ ) adjusted for age, sex, and baseline estimated glomerular filtration rate (eGFR) stratified by baseline eGFR categories including and excluding patients with hyperbilirubinemia (TB $>1.24 \mathrm{mg} / \mathrm{dL}) .(95 \%)=$ 95\% confidence interval)

\begin{tabular}{lcc}
\hline & odds ratio $(95 \%)$ & $\mathrm{p}$ \\
\hline including patients with hyperbilirubinemia & \\
\hline \multicolumn{2}{c}{ in patients with eGFR $\geq 15 \mathrm{~mL} / \mathrm{min} / 1.73 \mathrm{~m}^{2}(\mathrm{n}=6251)$} & \\
TB $(0.1 \mathrm{mg} / \mathrm{dL}$ increase) & $0.92(0.80-1.07)$ & 0.2804 \\
hypobilirubinemia & $3.51(1.56-7.88)$ & 0.0023 \\
\multicolumn{1}{c}{ in patients with eGFR $15-59 \mathrm{~mL} / \mathrm{min} / 1.73 \mathrm{~m}^{2}(\mathrm{n}=2165)$} & \\
TB (0.1 mg/dL increase) & $0.92(0.78-1.09)$ & 0.3560 \\
hypobilirubinemia & $3.21(1.31-7.80)$ & 0.0102 \\
$\quad$ in patients with eGFR $15-29 \mathrm{~mL} / \mathrm{min} / 1.73 \mathrm{~m}^{2}(\mathrm{n}=164)$ & \\
TB (0.1 mg/dL increase) & $0.59(0.37-0.95)$ & 0.0283 \\
hypobilirubinemia & $6.03(1.63-22.30)$ & 0.0071 \\
\hline excluding patients with hyperbilirubinemia & \\
\hline \multicolumn{3}{c}{ in patients with eGFR $\geq 15 \mathrm{~mL} / \mathrm{min} / 1.73 \mathrm{~m}^{2}(\mathrm{n}=5890)$} \\
TB (0.1 mg/dL increase) & $0.87(0.71-1.07)$ & 0.1901 \\
hypobilirubinemia & $3.46(1.53-7.85)$ & 0.0029 \\
$\quad$ in patients with eGFR $15-59 \mathrm{~mL} / \mathrm{min} / 1.73 \mathrm{~m}^{2}(\mathrm{n}=2054)$ & \\
TB (0.1 mg/dL increase) & $0.84(0.65-1.08)$ & 0.1700 \\
hypobilirubinemia & $3.24(1.30-8.09)$ & 0.0115 \\
$\quad$ in patients with eGFR $15-29 \mathrm{~mL} / \mathrm{min} / 1.73 \mathrm{~m}^{2}(\mathrm{n}=155)$ & \\
TB (0.1 mg/dL increase) & $0.59(0.37-0.95)$ & 0.0287 \\
hypobilirubinemia & $5.78(1.56-21.41)$ & 0.0086 \\
\hline
\end{tabular}

\section{Discussion}

In the present study, we demonstrated that TB was significantly lower in subjects with advanced renal dysfunction than in those with normal renal function and suggested that hypobilirubinemia may be a possible risk factor of ESKD independently of age, sex, and baseline eGFR.

The definition and classification for CKD was proposed by the National Kidney Foundation Kidney Disease Outcomes Quality Initiative (NKF-KDOQI) in 2002 and endorsed by the Kidney Disease: Improving Global Outcomes (KDIGO) in 2004 [17]. CKD is the primary cause of ESKD and is one of the major risk factors of CVD and all-cause mortality [3-7]. Not only ESKD but also less severe renal dysfunction increases the risk of death, CVD, and hospitalization [6]. Apart from CKD which consists of decreased eGFR and/or increased albuminuria, age, anemia, cigarette smoking, blood pressure, low HDL cholesterol, and fasting glucose independently predict ESKD [2]. However, to date, decreased TB has not been reported as an independent risk factor of ESKD.

As for cross-sectional associations between TB and eGFR, Fukui et al. found that TB was positively associated with eGFR in Japanese diabetic patients [12] and Shin et al. reported similar results in Korean diabetic and non-diabetic adults [13], while Targher et al. reported an opposite finding in both hospital-based unselected outpatients [14] and in the US general population [15]. In the present study, TB was significantly lower in S1 than in S2, in S3 than in S2, in S4 than in S3, and in S5 than in S4. We speculate that decrease in TB may reflect increased oxidative stress which is associated with renal dysfunction and that hyperbilirubinemia indicates possible liver disease which confounds the relationship between TB and eGFR. We think that TB was lower in S1 than in S2 because S1 includes glomerular hyper-filtration which is one of the early stages of renal dysfunction and may be associated with slightly increased oxidative stress.

Bilirubin is a potent antioxidant [8] and low serum TB levels may reflect increased oxidative stress. Some epidemiological studies suggest that low TB levels may be a risk factor 


\section{Kidney
Blood Pressure Research}

Kidney Blood Press Res 2012;36:47-54

\begin{tabular}{l|l}
\hline DOI: $10.1159 / 000339027$ & C 2012 S. Karger AG, Basel
\end{tabular}

Published online: July 24, 2012

www.karger.com/kbr

of CVD [9-11]. The flow-mediated dilatation of brachial artery [18] and coronary flow reserve [19] were significantly lower in subjects with lower TB and carotid intima-media thickness [18] and coronary artery calcification [20] were associated with lower TB. Balloon injuryinduced neointima formation is less in genetically hyperbilirubinemic rats and in wild-type rats treated with biliverdin, the precursor of bilirubin, than in controls and bilirubin inhibits the proliferation of vascular smooth muscle cells [21]. Oxidative stress and renal dysfunction may form a vicious cycle. Oxidative stress is one of the causal mechanisms of renal dysfunction and increases as renal dysfunction progresses as a result of increased oxidant activity and reduced antioxidant capacity [22]. Antioxidants may prevent the progression of renal dysfunction. Hyperbilirubinemia, acting as an antioxidant, can improve glomerular filtration rate and renal blood flow in a mouse model of angiotensin-induced hypertension [23]. An induction of heme oxigenase-1, which increases the bilirubin/biliverdin system, interrupts and counteracts the influence of the renin-angiotensin system to increase in blood pressure in renovascular hypertension rats [24]. In patients with mild to moderate CKD, a treatment strategy with antioxidants consisting of pravastatin, vitamin E, and homocysteine reduced carotid intima-media thickness and urinary albumin excretion and increased flow-mediated dilatation of brachial artery [25].

\section{Clinical Implications}

The results of the present study suggest that hypobilirubinemia which may indicate increased oxidative stress may be a possible risk factor of ESKD independently of baseline eGFR. The present results suggest that strategies aimed to increase TB such as cessation of smoking [9] and administration of TB increasing agents [26] may possibly prevent the progression of renal dysfunction to ESKD. CKD patients with hypobilirubinemia may be promising candidates for an antioxidant therapy and TB may be a useful marker of oxidative stress under antioxidant therapy in CKD patients.

\section{Limitations}

This study was not based on the general population but on unselected laboratory data in our Medical Center and the follow-up period was only more or less than one year. Other important outcomes of renal dysfunction than ESKD such as CVD and all-cause mortality were not examined and the OR was not adjusted for albuminura and other confounding factors because information about other laboratory data including albuminuria, hemoglobin, fasting glucose, or cholesterol and clinical backgrounds of the patients was not included in the present study. The longitudinal association was examined with logistic regression using only two time points because the exact follow-up period of each subject was not included in the study. Nevertheless, the present results suggested that hypobilirubinemia may be a possible risk factor of ESKD independently of baseline eGFR.

\section{Conflict of Interest Statement}

All authors have no conflict of interest to declare. The results presented in this paper have not been published previously in whole or part. The authors received no financial support.

\section{Acknowledgements}

We thank Mr Kazushi Takahashi for his assistance with collecting the laboratory data and appreciate an effort of deceased Dr Shinzo Tachikawa to found Chuetsu Kidney Center. 


\section{Kidney \\ Blood Pressure Research}

Kidney Blood Press Res 2012;36:47-54

\begin{tabular}{l|l} 
DOI: $10.1159 / 000339027$ & (C) 2012 S. Karger AG, Basel
\end{tabular}

Published online: July 24, 2012

www.karger.com/kbr

\section{References}

1 Coresh J, Selvin E, Stevens LA, Manzi J, Kusek JW, Eggers P, Van Lente F, Levey AS: Prevalence of chronic kidney disease in the United States JAMA 2007;298:2038-2047.

$\longrightarrow 2$ Ishani A, Grandits GA, Grimm RH, Svendsen KH, Collins AJ, Prineas RJ, Neaton JD: Association of single measurements of dipstick proteinuria, estimated glomerular filtration rate, and hematocrit with 25year incidence of end-stage renal disease in the multiple risk factor intervention trial. J Am Soc Nephrol 2006;17:1444-1452.

-3 Chronic Kidney Disease Prognosis Consortium, Matsushita K, van der Velde M, Astor BC, Woodward M, Levey AS, de Jong PE, Coresh J, Gansevoort RT: Association of estimated glomerular filtration rate and albuminuria with all-cause and cardiovascular mortality in general population cohorts: a collaborative meta-analysis. Lancet 2010;375:2073-81.

-4 Sarnak MJ, Levey AS, Schoolwerth AC, Coresh J, Culleton B, Hamm LL, McCullough PA, Kasiske BL, Kelepouris E, Klag MJ, Parfrey P, Pfeffer M, Raij L, Spinosa DJ, Wilson PW: American Heart Association Councils on Kidney in Cardiovascular Disease, High Blood Pressure Research, Clinical Cardiology, and Epidemiology and Prevention: Kidney disease as a risk factor for development of cardiovascular disease: a statement from the American Heart Association Councils on Kidney in Cardiovascular Disease, High Blood Pressure Research, Clinical Cardiology, and Epidemiology and Prevention. Circulation 2003;108:21542169.

-5 Keith DS, Nichols GA, Gullion CM, Brown JB, Smith DH: Longitudinal follow-up and outcomes among a population with chronic kidney disease in a large managed care organization. Arch Intern Med 2004;164:659-663.

6 Go AS, Chertow GM, Fan D, McCulloch CE, Hsu CY: Chronic kidney disease and the risks of death, cardiovascular events, and hospitalization. N Engl J Med 2004;351:1296-1305.

-7 Evans M, Fryzek JP, Elinder CG, Cohen SS, McLaughlin JK, Nyrén O, Fored CM: The natural history of chronic renal failure: results from an unselected, population-based, inception cohort in Sweden. Am J Kidney Dis 2005;46:863-870.

8 Stocker R, Yamamoto Y, McDonagh AF, Glazer AN, Ames BN: Bilirubin is an antioxidant of possible physiological importance. Science 1987;235:1043-1046.

-9 Breimer LH, Wannamethee G, Ebrahim S, Shaper AG: Serum bilirubin and risk of ischemic heart disease in middle-aged British men. Clin Chem 1995;41:1504-1508.

10 Troughton JA, Woodside JV, Young IS, Arveiler D, Amouyel P, Ferrières J, Ducimetière P, Patterson CC, Kee F, Yarnell JW, Evans A: PRIME Study Group: Bilirubin and coronary heart disease risk in the Prospective Epidemiological Study of Myocardial Infarction (PRIME). Eur J Cardiovasc Prev Rehabil 2007;14:79-84.

11 Oda E, Kawai R: A possible cross-sectional association of serum total bilirubin with coronary heart disease and stroke in a Japanese health screening population. Heart Vessels 2012;27:29-36.

-12 Fukui M, Tanaka M, Shiraishi E, Harusato I, Hosoda H, Asano M, Hasegawa G, Nakamura N: Relationship between serum bilirubin and albuminuria in patients with type 2 diabetes. Kidney Int 2008;74:1197-1201.

13 Shin HS, Jung YS, Rim H: Relationship of serum bilirubin concentration to kidney function and 24-hour urine protein in Korean adults. BMC Nephrol 2011;12:29.

14 Targher G, Zoppini G, Guidi GC: Relationship between serum bilirubin and kidney function in non-diabetic and diabetic individuals. Kidney Int 2009;75:863.

15 Targher G, Bosworth C, Kendrick J, Smits G, Lippi G, Chonchol M: Relationship of serum bilirubin concentrations to kidney function and albuminuria in the United States adult population. Findings from the National Health and Nutrition Examination Survey 2001-2006. Clin Chem Lab Med 2009;47:1055-1062.

-16 Matsuo S, Imai E, Horio M, Yasuda Y, Tomita K, Nitta K, Yamagata K, Tomino Y, Yokoyama H, Hishida A: Collaborators developing the Japanese equation for estimated GFR: Revised equations for estimated GFR from serum creatinine in Japan. Am J Kidney Dis 2009;53:982-992.

-17 Levey AS, de Jong PE, Coresh J, El Nahas M, Astor BC, Matsushita K, Gansevoort RT, Kasiske BL, Eckardt KU: The definition, classification, and prognosis of chronic kidney disease: a KDIGO Controversies Conference report. Kidney Int 2011;80:17-28.

18 Erdogan D, Gullu H, Yildirim E, Tok D, Kirbas I, Ciftci O, Baycan ST, Muderrisoglu H: Low serum bilirubin levels are independently and inversely related to impaired flow-mediated vasodilation and increased carotid intima-media thickness in both men and women. Atherosclerosis 2006;184:431-437. 


\section{Kidney \\ Blood Pressure Research}

Kidney Blood Press Res 2012;36:47-54

\begin{tabular}{l|l} 
DOI: $10.1159 / 000339027$ & (C) 2012 S. Karger AG, Basel
\end{tabular}

Published online: July 24, 2012 www.karger.com/kbr

19 Gullu H, Erdogan D, Tok D, Topcu S, Caliskan M, Ulus T, Muderrisoglu H: High serum bilirubin concentrations preserve coronary flow reserve and coronary microvascular functions. Arterioscler Thromb Vasc Biol 2005;25:2289-2294.

-20 Tanaka M, Fukui M, Tomiyasu K, Akabame S, Nakano K, Hasegawa G, Oda Y, Nakamura N: Low serum bilirubin concentration is associated with coronary artery calcification (CAC). Atherosclerosis 2009;206:287-291.

-21 Öllinger R, Bilban M, Erat A, Froio A, McDaid J, Tyagi S, Csizmadia E, Graça-Souza AV, Liloia A, Soares MP, Otterbein LE, Usheva A, Yamashita K, Bach FH: Bilirubin: a natural inhibitor of vascular smooth muscle cell proliferation. Circulation 2005;112:1030-1039.

22 Kao MPC, Ang DSC, Pall A, Struthers AD: Oxidative stress in renal dysfunction: mechanisms, clinical sequelae and therapeutic options. J Hum Hypertens 2010;24:1-8.

-23 Vera T, Stec DE: Moderate hyperbilirubinemia improves renal hemodynamics in ANG II-dependent hypertension. Am J Physiol Regul Integr Comp Physiol 2010;299:R1044-R1049.

24 Botros FT, Schwartzman ML, Stier CT Jr, Goodman AI, Abraham NG: Increase in heme oxygenase-1 levels ameliorates renovascular hypertension. Kidney Int 2005;68:2745-2755.

-25 Nanayakkara PW, van Guldener C, ter Wee PM, Scheffer PG, van Ittersum FJ, Twisk JW, Teerlink T, van Dorp W, Stehouwer CD: Effect of a treatment strategy consisting of pravastatin, vitamin E, and homocysteine lowering on carotid intima-media thickness, endothelial function, and renal function in patients with mild to moderate chronic kidney disease: results from the Anti-Oxidant Therapy in Chronic Renal Insufficiency (ATIC) Study. Arch Intern Med 2007;167:1262-1270.

26 McCarty MF: "Iatrogenic Gilbert syndrome"--a strategy for reducing vascular and cancer risk by increasing plasma unconjugated bilirubin. Med Hypotheses 2007;69:974-994. 